\title{
AFFORDABLE HOUSING FOR LOW-INCOME MASSES: A CASE STUDY OF A DENSELY POPULATED AREA IN LAGOS METROPOLIS
}

\author{
Oluranti Olupolola Ajayi ${ }^{*}$, Olajide Julius Faremi ${ }^{1}$, Simeon Dele Roger ${ }^{1}$, Antony Uwaje ${ }^{1}$ \\ ${ }^{1}$ Department of Building, Faculty of Environmental Sciences, University of Lagos, Nigeria
}

(Received: December 2019 / Revised: December 2019 / Accepted: February 2020)

\begin{abstract}
A house is an essential facility that affords an abode, provides habitation and shelter adequacies. Affordable housing presumes access to a conducive, functional, and sustainable dwelling by the majority of the people within a locality. The study investigated the factors mitigating the actualization of affordable housing for low-income masses in the selected area. Survey research was adopted for the study. The population for the study is made up of two groups comprising low-income masses and construction professionals. The study adopted a multi-sampling method. Both convenient and random sampling techniques were utilized to gather information from the respondents. Statistical Package for Social Sciences (SPSS) was used for descriptive (frequency, percent, and mean score) and appropriate inferential analysis. Results indicated factors weighing down the provision of affordable housing as well as factors precluding accessible housing for low-income masses. Also, the response from construction professionals showed the level of agreement on factors impeding the provision of affordable housing. The trail to alleviate the effect of the non-affordability of housing for low-income masses becomes perceptible and addressed.
\end{abstract}

Keywords: Affordable; Construction professionals; Housing; Low-income masses

\section{INTRODUCTION}

A house is a building that functions as a home or an abode that provides adequate shelter for individuals and families (Adenubi \& Windapo, 2007). Access to appropriate, accessible housing is a fundamental human right that is vital to the wellbeing of individuals, families, and communities (Select Committee, 2008). Housing plays an essential part in each country's financial growth, accounting for $10-20 \%$ of the country's total economic activity, as well as being the tremendous fixed asset of families (European Commission, 2005 as cited in Henilane, 2016). The need for housing is not only one of the fundamental human rights; it is the living standard measure of the population and also indirectly plays a crucial role in the wellbeing and economy of the country (Henilane, 2016).

Anderson et al. (2003) further explained that when low-income households do not have affordable housing, family resources needed for food, medical or dental care, and other necessities are diverted to housing costs. This turns out to be a cost worry or overburden, especially where $50 \%$ or more of household income is expended on housing rent.

*Corresponding author's email: ofarinloye@unilag.edu.ng

DOI: https://doi.org/10.32783/csid-jid.v3i1.89 
According to Quigley \& Raphael (2004), the average household spends about 25\% of income on housing expenses, while low class and near-low class households typically spend $50 \%$ of their income on housing. This is evident that a large number of household spending ranged above $30 \%$ and 50\% (Abimaje \& Akingbohungbe, 2014). These elevated ratios indicate that small percentage increases in housing prices and rents will have a significant effect on non-residential consumption such as food, recreation, learning, family maintenance, and wellbeing. According to the CAHF (2019), Nigeria has low ownership of housing rate of $25 \%$, lesser than that of Indonesia's $84 \%$, Kenya's 73\%, and South Africa's 56\%. This has a consequence on the availability of housing stock in Lagos with five million housing deficits (31\%) of the 18 million total national housing deficits. Presently, over $91 \%$ population of Lagos live in the city with a population density of about 20,000 people per square kilometer in the Metropolitan Lagos built-up areas. Likewise, about $72.5 \%$ of the total family occupied a one-room apartment with an occupancy ratio of 8-10 individuals per room (Lagos State Ministry of Housing, 2010, cited in Alufohai, 2013). Exposing them to a wide variety of negative impacts such as psychological distress, antisocial behavior, substance use, poor living condition, poor housing quality, overcrowding, and multiple moves caused by housing insecurity (Enterprise Community Partners, 2014; Kottke et al., 2017). Occupying a decent apartment by low-income earners is often impossible resulting in slum formation in cities (Adegun \& Adebusuyi, 2019). However, an effort has been made by both federal and state governments to provide quality, cost-efficient and affordable housing units to citizens through a housing scheme supported by public-private partnership efforts and private finance initiative models (Makinde, 2014). These attempts have a very restricted effect on housing requirements, particularly for the low and middle-income masses (Enisan \&Ogundiran, 2013), particularly the low-income masses that are non-public workers.

It is proven that the problems associated to affordable housing are not limited to rural-urban migration (Makinde, 2014), increasing cost of construction materials (Anacker, 2019; Adegun \& Adebusuyi, 2019), under research and low use of local building materials (Ajayi et al., 2016), low supply of housing to demand (Makinde, 2014; Robert et al., 2019), rapid urbanization and industrialization (Oni-Jimoh \& Liyanage, 2018) and growth of slums (Anofojie et al., 2014; Enisan \& Ogundiran, 2013). As such, the open choice for housing to low-income masses is often limited. It is in this view that this current study investigates factors hindering access to the provision of affordable housing. However, past studies relating to affordability of housing have dwelt with the matter in diverse manners with little or no preference given to the view of the lowincome masses including a study done by Economic Intelligence Unit [EIU] in 2012 that highlighted housing needs and examined the access challenges to affordable housing in Lagos, a study by Enisan \& Ogundiran (2013) that investigated factors affecting housing delivery in the Lagos Metropolis, and a study by Makinde (2014) that examined the constraints and challenges in accessing housing as well as factors responsible for high housing pricing trends. A study by Anofojie et al. (2014) assessed the quality of housing in Amuwo-Odofin in Lagos State while Ajayi et al. (2016) evaluated the strategies for affordable housing.

The aim of this study is to investigate factors mitigating the actualization of affordable housing for low-income masses. The specific objectives for the study include:

1. To assess the influence of factors deterring low-income masses from accessing affordable housing.

2. To assess factors thwarting the provision of affordable housing for low-income masses. 
The hypotheses postulated for the study are:

1. There is no difference in the perception of low-income masses and professionals on factors deterring access to affordable housing.

2. Factors thwarting the provision of affordable housing are not similarly perceived by the professionals.

\section{LITERATURE STUDY}

Housing is considered affordable if it consumes $30 \%$ or less of a household's income (Community Tool Box, 2018). The choice of an affordable house goes beyond having a roof over one's head; it involves choosing your neighborhood, amenities, and services that come (or don't come) with it (Wilson, 2018). The ability to access wealth by the majority of the citizen often puts upward pressure and competition from high-income masses on housing prices, thereby posting a higher risk for low-income masses (Community Tool Box, 2018).

In developing countries like Nigeria, it is often discussed that there are not enough affordable housing provisions, Nigeria is, in particular, the most populous African nation with 177 million population, and an annual growth rate of about $2.5 \%$. However, it is faced with substantial and progressive housing deficits. Subsequently, about 17 million new buildings are required to meet up with the housing deficit in the short-term (Rahimian et al., 2017). At the current rate of growth, one of its cities, Lagos, was set to be the world's third-largest city with a population of over 24 million by 2020 . Over the decades, the Lagos population has grown tremendously. The people of Lagos stood at 1.4 million, and 4.8 million in 1970 and 1990 respectively. The 2011 Revision of the World Urbanization Prospects ranked Lagos as the 19th most populous city in the world with a population of 11.2 million in 2011 and predicted that Lagos would surpass several other cities by 2025 to become the world's 11th most populous city with a population of 18.9 million (Opoko \& Oluwatayo, 2014).

There are associated problems in accessing affordable housing that include a high population rate, a single most top expenditure item for households, family spending up to half of their income on housing, (Community Tool Box, 2018; Czischke \& van Bortel, 2018). Affordable housing for low income shrinks continually while the concentration of housing needs by low-income masses are on the rise (Community Tool Box, 2018). Housing supply in Nigeria is mainly a function of the private sector, in which private developers produce about $90 \%$ of urban housing (Makinde, 2014). Often, they invest in housing units close to basic infrastructure and amenities, which are out of reach of low-income earners, while the remaining $10 \%$ could be accrued to the government housing investment for public workers leaving the non-public low-income masses with no housing security. This could be the reason for the presence of unplanned development activities and the lack of urban planning of densely populated areas built and occupied by low-income masses (Ajayi et al., 2014), A situation that is evident in the Makoko area. The difference between the amount a housing unit is expected to achieve from rents and the amount that developers will need to pay lenders and investors would stop affordable housing before it even begins. This could prevent housing developers from providing massive affordable housing, living a few or no options for the millions of low-income masses looking for affordable homes in a safe environment.

While it could be claimed that insufficient affordable housing issues are similar to developing nations, some distinct circumstances not limited to social wellbeing, housing standards and suitability, the housing market, transportation costs, households and their quality of life and political criteria (Ezennia \& Hoskara, 2019; Anacker, 2019) need to be noted. The problems that continue to affect housing provision in Nigeria include constraints on the high price of obtaining 
and registering secure land titles, insufficient access to finance, sluggish administrative procedures and high land expenses (CAHF, 2019), space, design, and quality standards adopted by designers among others (Adegun \& Adebusuyi, 2019). Another significant shortcoming was the property rights under the Land Use Act 1978, which gives the governors of each state ownership of all lands and is a substantial deterrent to housing and housing investments in Nigeria (Makinde, 2014).

Decent housing is an individual right, yet a large Nigerian population lives in a substandard, deplorable, and unsanitary residential setting (Simon et al., 2013; Michael et al., 2017). A physical and social slum situation is common with rental dwellings for the low-class people. Although there is a National Housing Policy to guarantee house for all, this intention has been on paper without any stern effort; this has been a mirage and frustration to mass expectations (Peterside, 2003 cited in Anofojie et al., 2014). The government needs to provide housing for its citizens; another thing is for the mass to be able to satisfy the costs (Makinde, 2014). People can only get what they can pay for. Since there is no financial structure for low-income access to mortgage funds from the National Housing Fund (Enisan \& Ogundiran, 2013). Evidence showed that most of the house units supplied were not accessed as a consequence of high costs, low social status, and living conditions. Only high-income earners can afford the Eko Atlantic city scheme (EIU, 2012).

Consequently, Enisan \& Ogundiran (2013) opine that the efforts made by the Lagos government and its various agencies to provide their citizen's homes are near perfect, but they seem far from reaching the low-income masses living in a high-density region. The letting housing could be made inexpensive to low-income households through measures that enhance housing provision like private rental policy options, proffering financial grant, flexible financing, lowering the price of land for housing development and loan guarantees (Czischke \& van Bortel, 2018; Anacker, 2019) or those that boost the acquiring power of low-income masses (Quigley \& Raphael, 2004), regulating the right and obligations under the tenancy agreement as well as offering housing units based on preferred households as being surveyed (EIU, 2012). Likewise, the initiation of resourceful services such as housing microfinance was efficiently implemented in other nations with comparable macroeconomic indicators (Okupe, 2002 cited in Makinde, 2014).

\section{METHODS}

This study adopted several methods, with a research survey being the first one, which was carried out in Makoko for its characteristics as one of the main slums that is highly populated with lowincome masses. Makoko falls within the metropolitan Lagos Southeast. It is bounded by Iwaya and the University of Lagos on the north, by Ebute-meta on the west, by the third mainland bridge on the south, and by the Lagos lagoon on the east (Simon et al., 2013). Makoko is a slum neighborhood with over 400,000 population living on water and land (Ajayi et al., 2014; Michael et al., 2017). The main economic activities are salt making, sawmills, firewood, and fishing. The areas are dominated by Ilajes, Eguns, and Yorubas, with a few Igbos and other ethnic groups.

This study also utilized a multi-sampling method, including both convenient and random sampling techniques to gather information from the respective respondents (Williams, 2007). The population for the study was masses residing in residential buildings on the streets of Makoko and construction professionals. There are 24 streets with a number of residential buildings ranging from 32 to 53 on each street. The average number of buildings in the area was estimated to be 1,020 buildings. The population of construction professionals (architects, builders, civil engineers, quantity surveyors, and estate surveyors) registered with the Lagos State Tender Board was estimated at 6,653. Using the simplified formula for proportions (Israel, 2013; Ali, 2014) at a $90 \%$ confidence level, likely sample proportion at $50 \%$ and precision at $5 \%$. A sample size of 
91 and 99 for residents of building units and professionals respectively were determined for the study. Two sets of copies of the questionnaire were developed as an instrument for collecting primary data for the research and administered on the two categories of respondents. The variables for the instrument were being identified through a comprehensive literature review. This list of variables was validated and simplified for the study.

The first set of copies of the questionnaire comprised of sections A and B. Section A was on demographic information of respondents, section B consist of a 24-item questionnaire. These copies of questionnaire were administered on the low in-income masses residing in the Makoko area who are conveniently available to participate in the study in order to assess the factors hindering their access to affordable housing. The second set of the copies of the questionnaire was randomly administered to professionals within the built environment field to assess the factors affecting the provision of affordable housing for low-income masses. These copies of the questionnaire distributed to professionals comprised of sections A, B, and C. Section A and B contained the same questions administered on low-income masses, while section $\mathrm{C}$ comprised a 22-item questionnaire.

A total of 91 copies of the questionnaire administered to the first category of respondents in their respective residences. Also, a total of 99 copies of the questionnaire was randomly administered to registered professionals in the built environment. A total of 23 copies of questionnaires were adequately completed by the resident of Makoko, while a total of 44 copies were completed by professionals. A response rate of $25 \%$ and $44 \%$ for low-income masses and professionals respectively were used for the study. The data collected through the completed questionnaires were statistically analyzed using statistic software (i.e., Statistical Package for Social Sciences, version 23). Frequency, percentage, mean scores were used as tools of analysis for the descriptive statistics, while Mann Whitney U test and Kendall's coefficient of concordance were used as the tools of analysis for the inferential statistics, respectively (Leard Statistics, 2018).

\section{RESULTS AND DISCUSSION}

The analysis for the questionnaire survey results shows that the population of male respondents was marginally higher than that of female respondents. The percentage of male to female was $65.2 \%$ to $38.4 \%$ and $84.1 \%$ to $15.9 \%$ for low income and professional, respectively. The demographic information of the respondents, which are shown below in Table 1, indicates that $43.4 \%$ of the low-income masses have OND, HND, and BSC qualifications, while $74.9 \%$ of professionals have the same kind of qualifications. The age of $47.8 \%$ of the low-income masses falls below 30 years while the age of others at 52.2\% falls between $30-49$ years. Likewise, the age of $65.9 \%$ professionals falls below 30 years while the remaining age at $34.2 \%$ falls between 30-59 years. This qualification attainment and age assured that the content of the questionnaire would be well understood and that the study would achieve quality responses.

The employment status of both low-income masses and built environment professionals categories was captured as well. The table also shows that for the low-income masses, $4.3 \%$ are employers, $17.4 \%$ are employees, while $52.2 \%$ are self-employed. Meanwhile, for professionals, $2.3 \%$ are employers, $31.8 \%$ are employees, while $38.6 \%$ are self-employed. Furthermore, the number of years that the low-income masses have resided in the study area was also indicated, in which $47.8 \%$ of low-income masses have lived in the locality for less than ten years, while $52.2 \%$ have resided for 10-19 years. This shows that they are conversant with the situation of the area. 
Table 1 Demographic profile of respondents

\begin{tabular}{|c|c|c|c|c|}
\hline \multirow[t]{2}{*}{ Profile } & \multicolumn{2}{|c|}{ Low-income masses } & \multicolumn{2}{|c|}{ Built environment professionals } \\
\hline & No & $\%$ & No & $\%$ \\
\hline \multicolumn{5}{|l|}{ Gender } \\
\hline Male & 15 & 65.2 & 37 & 84.1 \\
\hline Female & 8 & 34.8 & 7 & 15.9 \\
\hline Total & 23 & 100 & 44 & 100 \\
\hline \multicolumn{5}{|l|}{ Age } \\
\hline Less than 30 years & 11 & 47.8 & 29 & 65.9 \\
\hline 30-39 years & 6 & 26.1 & 8 & 20.5 \\
\hline 40-49 years & 6 & 26.1 & 5 & 11.4 \\
\hline $50-59$ & - & - & 1 & 2.3 \\
\hline Total & 23 & 100 & 44 & 100 \\
\hline \multicolumn{5}{|l|}{ Employment status } \\
\hline Employer & 1 & 4.3 & 2 & 2.3 \\
\hline Employee & 4 & 17.4 & 14 & 31.8 \\
\hline Self-employed & 12 & 52.2 & 17 & 38.6 \\
\hline Missing & 6 & 26.1 & 6 & 13.6 \\
\hline Total & 23 & 100 & 44 & 100 \\
\hline \multicolumn{5}{|l|}{ Qualifications } \\
\hline No formal education & 3 & 13 & - & - \\
\hline SSCE & 7 & 30.4 & 1 & 2.3 \\
\hline$N C E$ & 3 & 13 & - & - \\
\hline$O N D$ & 2 & 8.7 & 6 & 13.6 \\
\hline$H N D$ & 1 & 4.3 & 13 & 29.5 \\
\hline$B S C$ & 7 & 30.4 & 14 & 31.8 \\
\hline Others & - & - & 8 & 18.2 \\
\hline Missing & - & - & 2 & 4.5 \\
\hline Total & 23 & 100 & 44 & 100 \\
\hline \multicolumn{5}{|l|}{ Years of residences } \\
\hline Less than ten years & 11 & 47.8 & & \\
\hline 10-19 years & 12 & 52.2 & & \\
\hline Total & 23 & 100 & & \\
\hline
\end{tabular}

\subsection{Factors deterring low-income masses from accessing affordable housing.}

To assess the influence of factors deterring low-income masses from accessing affordable housing. The perception of low-income masses and construction professionals were viewed. In order to quantify the factors that are deterring access to affordable housing, a graduated scale of 1-5 was used, and the mean score calculated. The mean values were interpreted on a scale of 1$5 ; 1.00 \leq \mathrm{MS}<1.49$ means no influence, $1.50 \leq \mathrm{MS}<2.49$ means slight influence, $2.5 \leq \mathrm{MS}<$ 3.49 means somewhat influence, $3.50 \leq$ MS 4.49 means moderate influence, and $4.50 \leq \mathrm{MS} \leq$ 5.00 means strong influence. These factors were obtained from the studied literature.

Table 2 illustrates the descriptive analysis of factors deterring Low-Income Masses from accessing affordable housing. Table 2 shows the responses of the respondents on 24 factors deterring access to affordable housing. The mean scores of factors deterring access to affordable housing as perceived by low-income masses and professionals range from 4.74 to 3.13 . The five highly influential factors that deter access to accessible housing include; poor living conditions with a mean score of 4.74 , unemployment with a mean score of 4.61 , high poverty rate mean score 4.57, substance abuse, and the high-income gap between the rich and poor with a mean score of 4.52. Contrarily, the construction professional perceived no factor with a strong influence but perceived 15 factors having a moderate influence on accessing affordable housing. The first 
five factors perceived includes; unemployment with a mean score of 4.40 , cost of renting accommodation with a mean score of 4.16 , poverty rate with a mean score 4.14 , the high-income gap between the rich and poor with mean score 4.02, and cost of transportation with a mean score 4.00.

Table 2 Factors Deterring Low-Income Masses from Accessing Affordable Housing

\begin{tabular}{|c|c|c|c|c|c|c|}
\hline \multirow[t]{2}{*}{ Factors } & \multicolumn{2}{|c|}{$\begin{array}{l}\text { Low-income } \\
\text { perceptions }\end{array}$} & \multirow{2}{*}{$\begin{array}{c}\text { masses } \\
\text { Rank }\end{array}$} & \multicolumn{2}{|c|}{$\begin{array}{l}\text { Professionals } \\
\text { perceptions }\end{array}$} & \multirow[b]{2}{*}{ Rank } \\
\hline & $\mathbf{N}$ & MS & & $\mathbf{N}$ & MS & \\
\hline Poor living condition & 23 & 4.74 & 1 & 44 & 3.91 & 6 \\
\hline Unemployment & 23 & 4.61 & 2 & 43 & 4.40 & 1 \\
\hline High poverty rate & 23 & 4.57 & 3 & 44 & 4.14 & 3 \\
\hline Substance abuse & 23 & 4.52 & 4 & 43 & 3.74 & 11 \\
\hline High-income gap between the rich and poor & 23 & 4.52 & 5 & 43 & 4.02 & 4 \\
\hline Violence and human insecurity & 23 & 4.48 & 6 & 44 & 3.80 & 8 \\
\hline Poor environmental condition & 22 & 4.43 & 7 & 42 & 3.60 & 13 \\
\hline Cost of renting accommodation & 22 & 4.39 & 8 & 44 & 4.16 & 2 \\
\hline Presence of slums & 23 & 4.36 & 9 & 41 & 3.43 & 18 \\
\hline Natural disasters- flood & 23 & 4.35 & 10 & 44 & 3.27 & 21 \\
\hline $\begin{array}{l}\text { Location of housing is out of reach of basic } \\
\text { amenities }\end{array}$ & 23 & 4.17 & 11 & 44 & 3.48 & 16 \\
\hline Limited transportation options & 23 & 4.14 & 12 & 43 & 3.41 & 20 \\
\hline Low socioeconomic status & 23 & 4.04 & 13 & 43 & 3.58 & 15 \\
\hline Life-threatening disease within housing location & 23 & 3.96 & 14 & 43 & 3.42 & 19 \\
\hline Housing choice open to low-income earners & 23 & 3.96 & 15 & 43 & 3.60 & 13 \\
\hline Population growth & 23 & 3.91 & 16 & 44 & 3.84 & 7 \\
\hline Rent cost greater than $30 \%-50 \%$ of income & 23 & 3.91 & 17 & 44 & 3.77 & 10 \\
\hline Cost of transportation exceeds rent pay & 23 & 3.73 & 18 & 41 & 4.00 & 5 \\
\hline $\begin{array}{l}\text { Illegal industrial facilities within residential } \\
\text { premises }\end{array}$ & 22 & 3.71 & 19 & 42 & 3.00 & 24 \\
\hline Competition from high-income masses & 23 & 3.70 & 20 & 44 & 3.45 & 17 \\
\hline $\begin{array}{l}\text { Location of housing is out of reach of low-income } \\
\text { earners }\end{array}$ & 23 & 3.70 & 21 & 43 & 3.79 & 9 \\
\hline $\begin{array}{l}\text { Traveling distance from house location to the } \\
\text { workplace is lengthen }\end{array}$ & 23 & 3.61 & 22 & 44 & 3.66 & 12 \\
\hline Changing demographic structure & 20 & 3.59 & 23 & 43 & 3.24 & 22 \\
\hline Quick access to informal housing & 23 & 3.13 & 24 & 43 & 3.07 & 23 \\
\hline
\end{tabular}

Note: $\mathrm{N}$ is the number of Respondents; MS is the Mean Score.

\subsubsection{Hypotheses One}

The hypothesis one is that there is no difference in the perception of low-income masses and professionals on factors deterring access to affordable housing. The inferential analysis for this postulated hypothesis that there is no difference in the perception of low-income masses and professionals on factors deterring access to affordable housing is illustrated in Table 3. It shows that there are significant differences in the perception of respondents on 13 out of the 24 hypothesized factors deterring access to affordable housing. Factors deterring access to affordable housing for which there are significant differences and for which the null hypothesis is rejected; poor living condition, unemployment, high poverty rate, substance abuse, a highincome gap between the rich and poor, poor environmental condition, cost of renting accommodation, natural disasters- flood, location of housing is out of reach of basic amenities, limited transportation options, housing choice open to low-income earners, area of housing is out 
of reach of low-income earners, and traveling distance from house location to the workplace is lengthened.

Table 3 Mann- Whitney U test Results for comparing Perception of Low-Income Masses and Professionals on factors deterring access to affordable housing

\begin{tabular}{|c|c|c|c|c|c|c|c|}
\hline \multirow[t]{2}{*}{ Factors } & \multicolumn{2}{|c|}{$\begin{array}{l}\text { Low-income } \\
\text { masses perc }\end{array}$} & \multirow{2}{*}{\multicolumn{2}{|c|}{$\begin{array}{l}\text { Professionals } \\
\text { perceptions }\end{array}$}} & \multirow[t]{2}{*}{$\mathbf{U}$} & \multirow[t]{2}{*}{$\begin{array}{l}\text { P- } \\
\text { Value }\end{array}$} & \multirow{2}{*}{ Remark } \\
\hline & & & & & & & \\
\hline Poor living condition & 23 & 47.72 & 44 & 26.83 & 190.500 & .000 & $\mathrm{~S}$ \\
\hline Unemployment & 23 & 42.98 & 43 & 28.43 & 276.500 & .001 & S \\
\hline High poverty rate & 23 & 49.48 & 44 & 25.91 & 150.000 & .000 & S \\
\hline Substance abuse & 23 & 36.50 & 43 & 31.90 & 425.500 & .326 & $\mathrm{~S}$ \\
\hline $\begin{array}{l}\text { High-income gap between the rich and } \\
\text { poor }\end{array}$ & 23 & 39.35 & 43 & 30.37 & 360.000 & .051 & $\mathrm{~S}$ \\
\hline Violence and human insecurity & 23 & 38.28 & 44 & 31.76 & 407.500 & .169 & NS \\
\hline Poor environmental condition & 22 & 40.14 & 42 & 28.50 & 294.000 & .013 & $\mathrm{~S}$ \\
\hline Cost of renting accommodation & 22 & 39.00 & 44 & 30.75 & 363.000 & .075 & $\mathrm{~S}$ \\
\hline Presence of slums & 23 & 33.46 & 41 & 31.96 & 449.500 & .749 & NS \\
\hline Natural disasters- flood & 23 & 40.83 & 44 & 30.43 & 349.000 & .032 & $\mathrm{~S}$ \\
\hline $\begin{array}{l}\text { Location of housing is out of reach of } \\
\text { basic amenities }\end{array}$ & 23 & 41.50 & 44 & 30.08 & 333.500 & .017 & $\mathrm{~S}$ \\
\hline Limited transportation options & 23 & 39.72 & 43 & 30.17 & 351.500 & .046 & S \\
\hline Low socioeconomic status & 23 & 37.11 & 43 & 31.57 & 411.500 & .240 & NS \\
\hline $\begin{array}{l}\text { Life-threatening disease within housing } \\
\text { location }\end{array}$ & 23 & 36.52 & 43 & 31.88 & 425.000 & .334 & NS \\
\hline $\begin{array}{l}\text { Housing choice open to low-income } \\
\text { earners }\end{array}$ & 23 & 41.54 & 43 & 29.20 & 309.500 & .009 & S \\
\hline Population growth & 23 & 37.37 & 44 & 32.24 & 428.500 & .284 & NS \\
\hline $\begin{array}{l}\text { Rent cost greater than } 30 \%-50 \% \text { of } \\
\text { income }\end{array}$ & 23 & 34.35 & 44 & 33.82 & 498.000 & .911 & NS \\
\hline Cost of transportation exceeds rent pay & 23 & 35.48 & 41 & 30.83 & 403.000 & .310 & NS \\
\hline $\begin{array}{l}\text { Illegal industrial facilities within } \\
\text { residential premises }\end{array}$ & 22 & 35.86 & 42 & 30.74 & 388.000 & .282 & NS \\
\hline Competition from high-income masses & 23 & 35.70 & 44 & 33.11 & 467.000 & .591 & NS \\
\hline $\begin{array}{l}\text { Location of housing is out of reach of } \\
\text { low-income earners }\end{array}$ & 23 & 38.65 & 43 & 30.74 & 376.000 & .097 & $\mathrm{~S}$ \\
\hline $\begin{array}{l}\text { Traveling distance from house location } \\
\text { to the workplace is lengthen }\end{array}$ & 23 & 40.15 & 44 & 30.78 & 364.500 & .050 & $\mathrm{~S}$ \\
\hline Changing demographic structure & 20 & 32.20 & 43 & 31.91 & 426.000 & .949 & NS \\
\hline Quick access to informal housing & 23 & 33.96 & 43 & 33.26 & 484.000 & .883 & NS \\
\hline
\end{tabular}

Note: $p$ is significant at $p \leq 0.1$. $U$ is Mann- Whitney, $S=$ Significant difference exists, NS $=$ There is no significant difference.

Whereas, factors deterring access to affordable housing for which there are no significant differences between the perception of low-income masses and professional, and for which the null hypothesis is accepted include; violence and human insecurity, presence of slums, low socioeconomic status, life-threatening disease within housing location, population growth, rent cost greater than $30 \%-50 \%$ of income, cost of transportation exceed rent, illegal facilities within a residence, and competition from high-income masse as seen in Table 3. 


\subsubsection{Hypotheses Two}

The hypotheses two states that factors thwarting the provision of affordable housing are not similarly perceived by the professionals.

Table 4 shows Kendall's coefficient of concordance test used to test agreement among respondents in their ranking of 22 factors. It is most commonly used to assess agreement among raters or respondents. It shows the consensus among the ranks assigned by respondents on different objects or attributes. That is, the extent to which the respondents agree on factors upsetting the provision of affordable housing for low-income masses. The result indicated a significant agreement at $\mathrm{p}<0.1$ level; hence the null hypothesis was rejected.

Table 4 Kendall's coefficient of concordance test of agreement on the ranking of factors upsetting the provision of affordable housing for low-income masses

\begin{tabular}{lllll}
\hline $\mathrm{N}$ & Kendall's W & Chi-square & Df & P-value \\
\hline 38 & .128 & 101.827 & 21 & .000 \\
\hline
\end{tabular}

Note: $\mathrm{p}$ is significant at $\mathrm{p} \leq 0.1$. $\mathrm{W}$ is Kendall's coefficient of concordance test; $\mathrm{N}$ is the number of Respondents.

\subsection{Findings}

The study revealed the highly influenced perceived factors by low-income masses include poor living conditions, unemployment, and a high poverty rate. In the same vein, the professionals saw unemployment, cost of renting accommodation, and high poverty rate as influential factors. However, there is a significant difference in how these factors were recognized by the two categories of respondents, as seen in Table 3.

Relatively, this implies that accessing affordable housing is a mirage in the light of these striking issues. This is in accordance with the study conducted by Ankeli et al. (2017), which confirmed the economic recession of the country to have an adverse effect on employment, bring about the high rate of poverty as well as rising rental property prices. Similarly, this is supported by the finding of EIU (2012), which affirmed that most of the housing units are selling for more than double or even triple the ideal price that people are willing or capable of paying. Hence, selling prices for these apartments are not affordable for low-income and medium-income earners.

The first sixth factors agreed on by the professionals as significant factors affecting the provision of affordable housing include; land acquisition cost, price of land, cost of building materials, inadequate finance, national housing policy, and infrastructure. Also, all the 22 hypothesized factors were perceived similarly by the respondents. This implies that these factors are critical and capable of thwarting the provision of affordable housing. This finding substantiates the position of Enisan et al. (2014) that pinpointed land accessibility, land titling cost, inadequate finance, overpriced prices of building materials, absence of credit structure as problems affecting housing delivery in Lagos metropolis.

\section{CONCLUSION}

Affordable housing is relative in two dimensions that involve the provision (supply) of the housing unit as well as the citizen's ability to access and satisfy the costs of the housing units. On this notion, this study assessed various factors deterring provision and access to affordable housing. This study established the primacy of factors that prevent access to affordable housing that includes a high poverty rate, unemployment, and poor living conditions. This study also acknowledged that the constraint factors to the provision of affordable housing include land 
acquisition cost, price of land, cost of building materials, inadequate finance, national housing policy, and infrastructure.

The emphasis of this study lies in access to affordable housing for the low-income masses. Majorly, the low-income masses constitute the stakeholders in the quest for affordable housing. And as such, their participation should not be undermined in the development, supply, and ableness to satisfy the costs of affordable housing.

This study recommends that the government should see into making acquisition and titling of land more friendly as this would enable developers to invest more in housing development. More reasonable housing schemes should be encouraged by state governments, private institutions, and local communities, as well as poverty eradication that should be the utmost concern in society and empowerment programs that should be spread to the low earners to ensure their right living conditions and enable them to afford good shelter.

\section{REFERENCES}

Abimaje, J., \& Akingbohungbe, D. (2014). Housing affordability in Nigerian towns: a case of Idah, Nigeria. International Journal of Civil Engineering, Construction and Estate Management 1(2), 31-38

Adegun, O.B., Joseph, A., \& Adebusuyi, A.M. (2019). Housing affordability among low-income earners in Akure, Nigeria. IOP Conference Series: Materials Science and Engineering, 640, 012009. https://doi.org/10.1088/1757-899X/640/1/012009

Adenubi, O.I., \& Windapo A.O. (2007). A Study of Factors Affecting the Affordability of Urban Housing in Nigeria, Construction Research Journal (CRJ), 1, 1, 26-36

Ajayi, O., Ajayi, O., Akinsiku, O. \& Osunsanmi, T. (2016). Strategies for housing affordability in Nigeria, Journal of Construction Project Management \& Innovation, 6, 1620-1632.

Ajayi, O., Oviasogie, F.O., Azuh, D.E., \& Duruji, M.M. (2014). Urban Design and Sustainable Development: a Case of Makoko Area of Lagos State, Nigeria. European Scientific Journal, 10(10), 90-97

Ali, M. (2014). Sampling \& Sample Size Estimation. Geneva Foundation for Medical Education and Research. https://www.gfmer.ch/SRH-Course-2013/Geneva-Workshop/Samplingtechniques-Ali-2014.htm

Alufohai, A.J. (2013). The Lagos State 2010 Mortgage Law and The Supply of Housing. International Federation of Surveyors. FIG Working Week 2013 - Environment For Sustainability. Nigeria, 6-10 May 2013

Anacker, K.B. (2019). Introduction: housing affordability and affordable housing. International Journal of Housing Policy, 19(1), 1-16. https://doi.org/10.1080/19491247.2018.1560544

Anderson, L.M., Charles, J.S., Fullilove, M.T., Scrimshaw, S.C., Fielding, J.E., \& Normand, J. (2003). Providing Affordable Family Housing and Reducing Residential Segregation by Income: A Systematic Review. American Journal of Preventive Medicine, 24(3), 47-67. https://doi.org/10.1016/S0749-3797(02)00656-6

Ankeli, A.I., Dabara, I.D., Omotehinshe, J.O., Lawal, O.K., Odeyomi F.G. \& Adebowale, A.P. (2017). Affordable and acceptable mass housing delivery : a panacea to the Nigerian housing problem. Conference of the International Journal of Arts \& Sciences, 10(01), 31-38.

Anofojie, A.E., Adeleye O.A., Kadiri, M.A. (2014). Housing Quality Assessment in Selected Public Residential Estates in Amuwo-Odofin, L.G.A, Lagos, Nigeria. International Journal of Research In Earth \& Environmental Sciences, 2(6), 7-16.

CAHF. (2019). 2018 Housing Finance in Africa Yearbook (9 ${ }^{\text {th }}$ Edition). CAHF | Center for Affordable Housing Finance Africa. http://housingfinanceafrica.org/documents/housingfinance-in-africa-yearbook-2018/ 
Community Tool Box. (2018). Providing affordable housing for all. Center for community health and development. http://communityhealth.ku.edu/

Czischke, D., \& van Bortel, G. (2018). An exploration of concepts and policies on 'affordable housing' in England, Italy, Poland and The Netherlands. Journal of Housing and the Built Environment, 1-21. https://doi.org/10.1007/s10901-018-9598-1

EIU. (2012). Meeting Housing Needs in Lagos: EIU Policy Brief. (1), 1-4

Enisan, O. \& Ogundiran, A. (2013). Challenges of Housing Delivery in Metropolitan Lagos. Research on Humanities and Social Sciences, 3(20), 1-8

Enterprise Community Partners. (2014). Impact of Affordable Housing on Families and Communities: Impact of Affordable Housing on Families and Communities: A Review of the Evidence Base. 1-17. www.EnterpriseCommunity.org.

Ezennia, I.S., \& Hoskara, S.O. (2019). Methodological weaknesses in the measurement approaches and concept of housing affordability used in housing research: A qualitative study. PLOS ONE, 14(8), e0221246. https://doi.org/10.1371/journal.pone.0221246

Henilane, I. (2016). Housing Concept and Analysis of Housing Classification. Baltic Journal of Real Estate Economics and Construction Management, 4(1), 168-179. https://doi.org/10.1515/bjreecm-2016-0013

Israel, G.D. (2013). Determining Sample Size 1. University of Florida, IFAS Extension. https://www.tarleton.edu/academicassessment/documents/Samplesize.pdf

Kottke, T., Abariotes, A., \& Spoonheim, J.B. (2017). Access to Affordable Housing Promotes Health and Well-Being and Reduces Hospital Visits. The Permanente Journal, 22, 15-18. https://doi.org/10.7812/TPP/17-079

Laerd Statistics. (2018). Kendall's Tau-b using SPSS. https://statistics.laerd.com

Makinde, O.O. (2014). Housing delivery system, need and demand. Environment, Development and Sustainability, 16(1), 49-69. https://doi.org/10.1007/s10668-013-9474-9

Michael, A.O., Isaac, O.O., \& Olusola, O.P. (2017). Urban renewal strategies in developing nations: A focus on Makoko, Lagos State, Nigeria. Journal of Geography and Regional Planning, 10(8), 229-241. https://doi.org/10.5897/jgrp2017.0631

Oni-Jimoh, T., \& Liyanage, C. (2018). Urbanization and Meeting the Need for Affordable Housing in Nigeria. Housing. https://doi.org/10.5772/intechopen.78576

Opoko, A.P., \& Oluwatayo, A. (2014). Trends in Urbanisation: Implication for Planning and Low-Income Housing Delivery in Lagos, Nigeria. Architecture Research, 4, 15-26.

Quigley, J.M., \& Raphael, S. (2004). Is Housing Unaffordable? Why Isn't It More Affordable? 18(1). Journal of Economic Perspectives, 18(1), 191-214.

Rahimian, F.P., Goulding, J., Akintoye, A., \& Kolo, S. (2017). Review of Motivations, Success Factors, and Barriers to the Adoption of Offsite Manufacturing in Nigeria. Procedia Engineering, 196, 512-519. https://doi.org/10.1016/j.proeng.2017.07.232

Robert, O., Chan, A.P.C., \& Effah, E.A. (2019, November 6-8). Public-Private Partnership for affordable housing delivery in Ghana: Experience of the Ghana National Housing Project and Policy Implications. Aubea Conference, Queensland, QLD, Australia.

Select Committee on Housing Affordability in Australia (2008) A Good House is Hard to Find: Housing Affordability in Australia, The Senate, Commonwealth of Australia.

Simon, R.F., Adegoke, A.K., \& Adewale, B.A. (2017). Slum settlement regeneration in Lagos Mega-city : an Overview of a Waterfront Makoko Community. International Journal of Education and Research 1(3),1-16

Williams, C. (2007). Research methods. Journal of Business \& Economic Research (JBER), 5, (3), 65-72. https://doi.org/10.19030/jber.v5i3.2532

Wilson, K. (2018, April 11). 4 Factors that can Make Affordable Housing not so AffordableStrong Towns. https://www.strongtowns.org/journal/2018/4/10/4-factors-that-can-makeaffordable-housing-not-so-affordable 